\title{
Strategiczni myśliciele w świetle przeglądu literatury i studiów biograficznych
}

Anna Witek-Crabb

Uniwersytet Ekonomiczny we Wrocławiu Wydział Zarządzania, Katedra Zarządzania Strategicznego

\begin{abstract}
Katarzyna Piórkowska
Uniwersytet Ekonomiczny we Wrocławiu, Wydział Zarządzania Katedra Strategii i Metod Zarządzania
\end{abstract}

Janusz Marek Lichtarski

Uniwersytet Ekonomiczny we Wrocławiu, Wydział Zarządzania Katedra Strategii i Metod Zarządzania

Sylwia Wrona

Uniwersytet Ekonomiczny we Wrocławiu, Wydział Zarządzania Katedra Strategii i Metod Zarządzania

Maciej Adam Wilczyński Uniwersytet Ekonomiczny we Wrocławiu, Wydział Zarządzania Katedra Strategii i Metod Zarządzania

\section{Wprowadzenie}

Indywidualne uwarunkowania decyzji strategicznych stanowią istotny nurt badawczy w ramach zarządzania strategicznego. Procesy związane z percepcją, przetwarzaniem i oceną informacji oraz wynikające $z$ nich wybory strategiczne podejmowane przez liderów to stosunkowo rzadko eksplorowany i obiecujący obszar badawczy. Badacze od lat podejmują próby identyfikacji cech tzw. myślicieli strategicznych 
(strategic thinkers) ${ }^{1}$, poszukując podobieństw pomiędzy nimi i pewnych uniwersalnych zasad ${ }^{2}$. Jednocześnie można zauważyć, że znacznie mniejszą uwagę w badaniach przywiązuje się do cech różnicujących poszczególnych strategów (myślicieli strategicznych), a perspektywa ta wydaje się ważna i interesująca, ponieważ - jak podkreślają Olson i Simmerson ${ }^{3}$ - pomiędzy strategami występują wyraźnie obserwowalne różnice. Należy podkreślić, że różnice te dotyczą między innymi percepcji otoczenia i sposobów myślenia, a nie jedynie cech osobowości (co jest poza obszarem bezpośredniego zainteresowania autorów) i znajdują odzwierciedlenie zarówno w wielu różnych strategiach oraz zachowaniach strategicznych ${ }^{4}$, jak i w różnym przebiegu procesu myślenia strategicznego i formułowania strategii organizacji.

Celem niniejszego opracowania jest syntetyczne przedstawienie podstaw teoretycznych koncepcji myślenia strategicznego i myślicieli strategicznych, a także cech różnicujących strategów, w głównej mierze poprzez ich egzemplifikację na podstawie sylwetek znanych przedstawicieli świata biznesu. Cel został zrealizowany poprzez poszukiwanie odpowiedzi na następujące badania badawcze:

- „Jakie są podwaliny teoretyczne koncepcji myślenia strategicznego i myślicieli strategicznych?";

- „Jakie są podstawowe charakterystyki orientacji strategic thinkers?”;

- „Jakie są podstawowe cechy różnicujące strategicznych myślicieli i czy można je wyłonić w badaniach biograficznych?".

Zastosowane metody badawcze to systematyczno-krytyczny przegląd literatury oraz metoda biograficzna.

Układ opracowania jest następujący: w pierwszej kolejności zaprezentowano syntetycznie fundamenty poznawcze koncepcji myślenia strategicznego i myślicieli strategicznych (w wymiarze cech wyróżniających i odróżniających). W kolejnej części przedstawiono założenia całości realizowanego projektu badawczego oraz zastosowane metody badawcze. Następnie, na bazie podbudowy teoretycznej, przedstawiono wyniki badań biograficznych, stanowiące egzemplifikację cech różnicujących strategów/myślicieli strategicznych. Ostatnia część zawiera podsumowanie badań,

1 Zob. L. Heracleous, Strategic thinking or strategic planning?, „Long Range Planning” 1998, vol. 31, no. 3, s. 481-487; J.M. Liedtka, Strategic thinking: can it be taught?, „Long Range Planning” 1998, vol. 31, no. 1, s. 120-129; H. Mintzberg, The Rise and Fall of Strategic Planning, Hertfordshire Free Press and Prentice Hall International, London 1994; M.E. Porter, On competition, Harvard Business Press, Boston 2008.

2 D.B. Yoffie, M.A. Cusumano, Strategy Rules: Five Timeless Lessons from Bill Gates, Andy Grove, and Steve Jobs, Harper Business, New York 2015.

3 A.K. Olson, B.K. Simerson, Leading with strategic thinking: Four ways effective leaders gain insight, drive change, and get results, John Wiley \& Sons, Hoboken 2015.

4 Tamże; D.L. Schachter i wsp., Introducing psychology, Worth, New York 2015. 
sygnalizuje ich ewentualne ograniczenia oraz wskazuje na kolejne zamierzenia badawcze autorów i dalsze kierunki badań w tym obszarze.

Projekt jest finansowany w ramach programu Ministra Nauki i Szkolnictwa Wyższego pod nazwą „Regionalna Inicjatywa Doskonałości” w latach 2019-2022, nr proj. 15/RID/2018/19, kwota finansowania 10721 040,00 PLN.

\section{Założenia projektu badawczego i metody badawcze}

W niniejszym rozdziale zaprezentowano syntetyczne wyniki pierwszej fazy postępowania badawczego oraz wstępne wyniki fazy drugiej (studia biograficzne) w ramach projektu „TYPY STRATEGÓW - identyfikacja typów strategów i sposobów myślenia strategicznego". Całość postępowania badawczego przedstawia rysunek 1.

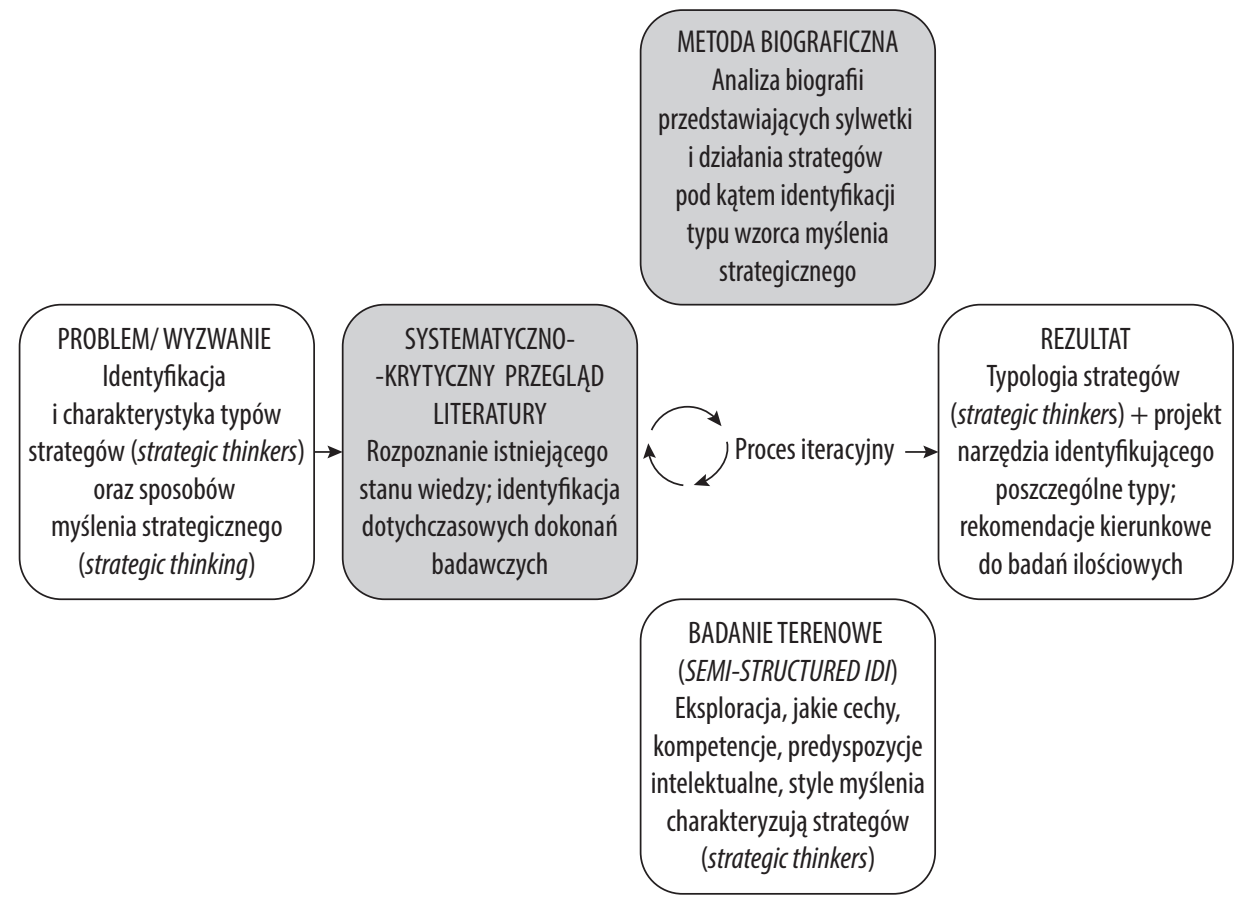

Rysunek 1. Postępowanie badawcze w ramach projektu „TYPY STRATEGÓW - identyfikacja typów strategów i sposobów myślenia strategicznego" 
Procedura badawcza całego projektu obejmie:

- systematyczno-krytyczny przegląd literatury;

- badania biograficzne oraz

- badania terenowe realizowane techniką częściowo ustrukturyzowanego indywidualnego wywiadu pogłębionego.

Niniejsze opracowanie odnosi się do pierwszych dwóch etapów.

Oczekiwanym wynikiem tak określonego postępowania badawczego jest typologia strategów (strategic thinkers) oraz projekt narzędzia identyfikującego poszczególne typy, a także sformułowanie wniosków i rekomendacji kierunkowych do dalszych badań (kolejne zamierzenie badawcze to przeprowadzenie badań ilościowych).

Punktem wyjścia w postępowaniu badawczym stały się studia literaturowe (podstawowe rozeznanie z zakresu literatury przedmiotu) z zastosowaniem systematyczno-krytycznego przeglądu literatury. Dla potrzeb identyfikacji i wstępnej oceny dotychczasowego stanu wiedzy w badanym obszarze przeprowadzono proces, który poprzez użycie powtarzalnej i dokładnie opisanej procedury pozwala na odszukanie, selekcję, krytyczną ocenę i syntezę kluczowych źródeł wiedzy adekwatnych do problemu badawczego ${ }^{5}$.

Do systematycznego przeglądu literatury wykorzystano pełnotekstową, obejmującą większość czasopism z zakresu zarządzania strategicznego, anglojęzyczną bazę Scopus. Przedmiot zainteresowań zdefiniowano następującymi kodami strategic thinking oraz strategic thinkers ( $\mathrm{w}$ dowolnym miejscu). W rezultacie przeszukiwań na 12 czerwca 2019 roku uzyskano 1296 publikacji. Następnie nałożono kryteria inkluzji:

- obszar „Business, Management \& Accounting” (461 tekstów) oraz

- pełnotekstowe, recenzowane publikacje (146 tekstów).

Jako badawczo istotne uznano te publikacje, których głównym obiektem analiz był termin strategic thinking oraz strategic thinkers umieszczony w ty tule, abstrakcie i słowach kluczowych. Po analizie abstraktów uzyskano 56 publikacji. Dodatkowo w procedurze „kuli śnieżnej” (publikacje z referencji) do analizy dołączono 8 publikacji. Ostatecznie analiza objęła 64 publikacje z lat 1998-2018 (przeglądy literaturowe: 10, badania ilościowe: 9 , badania jakościowe: 16 , artykuły teoretyczne i koncepcyjne: 20, inne: 9).

Celem przeglądu i analizy literatury było zapoznanie się z wynikami badań zbliżonych, umieszczenie projektu w szerszym kontekście, stworzenie ram konceptualnych dla badań empirycznych oraz dostarczenie wzorca, do którego będzie

5 Zob. A. Booth, A. Sutton, D. Papaioannou, Systematic approaches to a successful literature review, Sage, London 2016; W. Czakon, Metodyka systematycznego przeglqdu literatury, „Przegląd Organizacji” 2011, nr 3, s. 57-61; M. Petticrew, H. Roberts, Systematic Reviews in the Social Sciences: A Practical Guide, Blackwell, Oxford 2006. 
można odnieść wyniki uzyskane w badaniach terenowych. Należy zwrócić uwagę, że w niniejszym rozdziale, ze względu na ograniczenia objętościowe, zaprezentowano syntetyczne i podstawowe wyniki analizy literatury.

Zastosowana w drugim etapie postępowania badawczego metoda biograficzna wykorzystywana jest do zbierania, analizowania i interpretowania informacji o jednostkach - ich życiu, cechach, postawach i zachowaniach ${ }^{6}$. Obejmuje ona analizę wspomnień i zapisków, dzienników, korespondencji, biografii i krótkich, kontekstowych opisów biograficznych, tzw. shorter biografical portraits ${ }^{7}$. W naukach o zarządzaniu rekomendowana jest między innymi w badaniach nad identyfikacją cech (również patologicznych), sposobów myślenia, zrozumieniem ukrytych motywów działania jednostek (przywódców/menedżerów) w powiązaniu z kontekstem organizacyjnym/historycznym ${ }^{8}$.

Do egzemplifikacji cech różnicujących typy strategów dobrano powszechnie znane postaci świata biznesu, spełniające określone kryteria inkluzji9:

- osoby, które zajmują/zajmowały najwyższe szczeble kierownicze w organizacjach, mając tym samym realny wpływ na ich strategię i zachowania strategiczne;

- osoby, które posiadają/posiadały autonomię w kształtowaniu strategii organizacji, rozumianą jako brak wpływu instytucji i organów nadrzędnych (np. centrali koncernu czy decyzji politycznych);

- osoby, które wykazują/wykazywały cechy charakterystyczne dla myślicieli strategicznych, takie jak: całościowa i długookresowa perspektywa, koncentracja na wizji i intencjach, systemowe podejście, uważność, refleksyjność oraz kreatywność.

6 J. Bornat, Biographical methods. The Sage Handbook of Social Research Methods, Sage, London 2008.

7 H. Gunter, Leaders and leadership in education, Sage, London 2001.

8 J. Brandon, Toward a reconsideration of biography as an instrument for studying leadership in educational administration, „Canadian Journal of Educational Administration and Policy” 2002, vol. 21, http://www.umanitoba.ca/publications/cjeap/articles/brandon.html (dostęp: 2.02.2020); A.B. Danzig, Leadership stories: What novices learn by crafting the stories of experienced school administrators, „Journal of Educational Administration” 1997, vol. 35, no. 2, s. 122-137.

9 Zob. S. Dhir, S. Dhir, P. Samanta, Defining and developing a scale to measure strategic thinking, „Foresight” 2018, vol. 20, no. 3, s. 271-288; K. Dutta, Strategic Thinking as a Differentiator in Entrepreneurial Cognition, „The IUP Journal of Entrepreneurship Development” 2015, vol. 12, no. 2, s. 7-23; J.M. Liedtka, Strategic thinking...; T. Palaima, A. Skaržauskienè, Systems thinking as a platform for leadership performance in a complex world, „Baltic Journal of Management” 2010, vol. 5, no. 3, s. 330-355; C.R. Ribeiro, „Thought of the outside”, knowledge and thought in education: conversations with Michel Foucault, „Educação e Pesquisa" 2011, vol. 37, no. 3, s. 613-628. 
Analizy dokonano na dwóch poziomach:

- opis działań i decyzji podejmowanych przez badane osoby, ujęty w studiach biograficznych oraz

- określenia/słowa występujące w opisach działań i sposobach myślenia danej osoby.

$\mathrm{Z}$ uwagi na ograniczone ramy objętościowe niniejszego opracowania dla każdej wyróżnionej cechy dobrano po jednym przykładzie.

\section{Strategiczne myślenie i myśliciele strategiczni - podstawy teoretyczne}

Strategiczne myślenie (strategic thinking), chociaż zakorzenione w różnych dyscyplinach/teoriach/koncepcjach, znajduje również swoje semantyczne i poznawcze odzwierciedlenie w zarządzaniu strategicznym ${ }^{10}$. Koncepcja strategicznego myślenia egzemplifikuje się w poszukiwaniu innowacyjnych sposobów działania oraz w zróżnicowanych indywidualnych postawach, mogących prowadzić do redefiniowania strategii przedsiębiorstwa ${ }^{11}$. Co więcej, strategiczne myślenie i procesy w nim rezydujące dotyczą przyszłych kierunków działań przedsiębiorstwa i przewidywanych zmian w otoczeniu ${ }^{12}$.

W wyniku analizy literatury można skonstatować, iż w odniesieniu do strategicznego myślenia wyłaniają się dwa podstawowe nurty badawcze, tj. Mintzbergowski i Porterowski.

Podejście Mintzbergowskie dotyczy zmian w strategii per se. Strategiczne myślenie rozumiane jest w tym ujęciu jako specyficzny sposób myślenia, łączący kreatywność, intuicję i nieokreślony (stwarzający możliwość dowolnej interpretacji) proces poznania (open-ended cognition). Stanowi ono również zintegrowaną perspektywę prowadzącą do długoterminowych działań przedsiębiorstwa ${ }^{13}$. Innymi słowy, strategiczne myślenie prowadzi do wyłonienia się obszarów konstytuujących kierunek działania przedsiębiorstwa, który stanowi odpowiedź na warunki otoczenia, w jakim dany podmiot funkcjonuje ${ }^{14}$. Ponadto w ujęciu Mintzbergowskim

10 M. Amitabh, A. Sahay, Strategic Thinking: Is Leadership the Missing Link, 2007, http://www.iitk.ac.in /infocell/announce/convention/papers/Strategy-01-ManuAmitabhfinal.pdf(dostęp: 2.02.2020).

11 K. Haycock, A. Cheadle, K.S. Bluestone, Strategic Thinking Lessons for Leadership from the Literature, „Library Leadership and Management” 2012, vol. 26, no. 3/4, s. 1-23.

12 E.F. Goldman, A.R. Scott, J.M. Follman, Organizational practices to develop strategic thinking, „Journal of Strategy and Management” 2015, vol. 8, no. 2, s. 155-175.

13 H. Mintzberg, The Rise and Fall...

14 E.F. Goldman, A.R. Scott, J.M. Follman, Organizational practices...; I. Tavakoli, J. Lawton, Strategic thinking and knowledge management, „Handbook of Business Strategy” 2005, vol. 6 , no. 1 , s. $155-160$. 
strategiczne myślenie ujawnia się w modelach mentalnych menedżerów, które dotyczą działań przedsiębiorstwa i warunków otoczenia ${ }^{15}$, i jako takie wpisuje się jako wyróżniająca cecha strategicznego przywódcy ${ }^{16}$.

Podejście Porterowskie odnosi się natomiast do zmian w strategiach konkurencyjnych. Strategiczne myślenie pojmowane jest tutaj jako indywidualna dyspozycja umożliwiająca tworzenie strategii konkurencyjnej w celu zbudowania zamierzonej pozycji w sektorze ${ }^{17}$. Zwraca się również uwagę, że strategiczne myślenie w podejściu tym rozumiane jest jako kreatywny, innowacyjny i niekonwencjonalny sposób myślenia, prowadzący z jednej strony do przewagi konkurencyjnej, a z drugiej do nowych zasad gry konkurencyjnej, wspieranych przez nowatorskie strategie konkurencyjne ${ }^{18}$. Można również spotkać w literaturze stanowiska badawcze traktujące strategiczne myślenie jako kompetencję analityczną (nurt Porterowski) oraz dywergentną i kreatywną (nurt Mintzbergowski) ${ }^{19}$, co jednak w obliczu powyższych konstatacji wydaje się dużym uproszczeniem.

Strategiczne myślenie jako poznawcza koncepcja eksplorowana w zarządzaniu strategicznym przekłada się jednocześnie na jej praktyczny aspekt - postać stratega (strategic thinker) wraz z jego wyróżniającymi się i odróżniającymi cechami.

Myśliciel strategiczny (strategic thinker), określany w opracowaniu zamiennie jako strateg, jest najczęściej identyfikowany jako lider podejmujący w przedsiębiorstwie decyzje ${ }^{20}$ i ponoszący odpowiedzialność za zarządzanie organizacją ${ }^{21}$.

Myślenie strategiczne, na które składają się procesy gromadzenia i przetwarzania informacji o organizacji i jej otoczeniu, tworzenia modeli myślowych i heurystyk oraz oceny informacji i podejmowania decyzji, stanowi obecnie jeden z czynników różnicujących liderów i stanowiących potencjalne źródło przewagi konkurencyjnej organizacji. Zdolność myślenia strategicznego lidera przyczynia się do poprawy wyników i zyskowności przedsiębiorstwa ${ }^{22}$ poprzez większą gotowość

15 W. Rouse, Technology for Strategic Thinking, „Strategy \& Leadership” 1997, vol. 25, no. 1, s. $40-41$.

16 J. Pisapia, The Strategic Leader: New Tactics for a Globalizing, Information Age Publishing, USA 2009.

17 Między innymi E.F. Goldman, K.S. Schlumpf, A.R. Scott, Combining practice and theory to assess strategic thinking, „Journal of Strategy and Management” 2017, vol. 10, no. 4, s. 488-504.

18 L. Heracleous, Strategic thinking...; J.M. Liedtka, Strategic thinking...

19 L. Heracleous, Strategic thinking...

20 K.M. Eisenhardt, Speed and Strategic Choice: How Managers Accelerate Decision Making, „California Management Review” 1990, vol. 32, no. 3, s. 39-54.

21 G. Steptoe-Warren, D. Howat, I. Hume, Strategic thinking and decision making: literature review, „Journal of Strategy and Management” 2011, vol. 4, no. 3, s. 238-250.

22 E.H. Bowman, C.E. Helfat, Does corporate strategy matter?, „Strategic Management Journal" 2001, vol. 22, no. 1, s. 1-23. 
organizacji do adekwatnego reagowania na zmiany w otoczeniu biznesowym ${ }^{23}$. Stąd często pojęcie myśliciela strategicznego łączy się z osobami odpowiedzialnymi za sukces przedsiębiorstwa 24 .

Według przyjętych w niniejszym rozdziale założeń myśliciela strategicznego można odróżnić od innych przywódców na podstawie dwóch kryteriów, tj. kryterium przyjmowanej perspektywy oraz kryterium stosowanego stylu myślenia.

Strateg jest osobą, dla której charakterystyczne jest przyjmowanie perspektywy strategicznej (w odróżnieniu od perspektywy operacyjnej) oraz stosowanie refleksyjnego stylu myślenia. Najważniejsze przejawy perspektywy strategicznej to:

- daleki horyzont myślenia o rozwoju organizacji i zdolność do planowania go w czasie 25 ;

- holistyczne widzenie przedsiębiorstwa w otoczeniu oraz

- wizjonerska otwartość na zmiany, prowadząca do przełomowych rozwiązań $^{26}$.

Drugim kryterium, które odróżnia strategów od pozostałych przywódców, jest refleksyjny styl myślenia, który opiera się na:

- świadomości, wglądzie i refleksji ${ }^{27}$ oraz

- zdolności uczenia się28.

Strateg myśli i podejmuje decyzje w sposób świadomy, na podstawie refleksji zarówno nad swoimi wcześniejszymi decyzjami, jak i nad samym procesem rozumowania, którego jest podmiotem. Tym sposobem nieustannie uczy się oraz podejmuje decyzje w sposób celowy, nieprzypadkowy i na bazie wglądu. Dzięki temu w przypadku myślicieli strategicznych można mówić o procesie uczenia się na zasadzie podwójnej pętli, dla którego charakterystyczne jest podważanie dotychczasowych założeń i przekonań, aby wypracowywać innowacyjne rozwiązania ${ }^{29}$. Myśliciel strategiczny to bardziej ktoś, kto się uczy, niż ktoś, kto wie ${ }^{30}$.

Jednocześnie, jak wspomniano, pomiędzy strategami występują wyraźnie obserwowalne różnice, mające swoje odzwierciedlenie zarówno w strategii organizacji,

23 I. Tavakoli, J. Lawton, Strategic thinking...

24 P. Nuntamanop, I. Kauranen, B. Igel, A new model of strategic thinking competency, „Journal of Strategy and Management" 2013, vol. 6, no. 3, s. 242-264.

25 P. Hanford, Developing Director and Executive Competencies in Strategic Thinking, [w:] B. Garratt (red.), Developing Strategic Thought: Reinventing the Art of Direction-Giving, McGraw-Hill, London 1995, S. 188-222; J.M. Liedtka, Strategic thinking...

26 G. Hamel, C.K. Prahalad, Strategy as stretch and leverage, „Harvard Business Review” 1993, vol. 71, no. 2, s. 75-84; L. Heracleous, Strategic thinking...

27 S. Dhir, S. Dhir, P. Samanta, Defining and developing...

28 J.M. Liedtka, Strategic thinking...

29 L. Heracleous, Strategic thinking...

30 J.M. Liedtka, Strategic thinking... 
jak i w przebiegu procesu myślenia strategicznego oraz formułowania strategii. Zidentyfikowane na podstawie studiów literaturowych cechy różnicujące strategów można uporządkować w dwóch grupach. Pierwszą stanowią cechy związane z treścią myślenia strategicznego, takie jak podejście do zmian czy postrzeganie otoczenia w perspektywie jego wrogości/przyjazności (tzw. obszar merytoryczny). Drugą grupę stanowią cechy związane z samym przebiegiem procesu myślenia strategicznego - między innymi z tym, czy jest on indywidualny, czy kolektywny lub czy jest to działalność systematyczna, czy okazjonalna (tzw. obszar metodyczny). Syntetyczne zestawienie cech różnicujących myślicieli strategicznych zaprezentowano w tabeli 1.

Tabela 1. Syntetyczne zestawienie cech różnicujących strategów (myślicieli strategicznych)

\begin{tabular}{|c|c|c|}
\hline \multicolumn{3}{|c|}{ Obszar merytoryczny (treść) } \\
\hline Kryterium & Cecha & Referencje \\
\hline $\begin{array}{l}\text { Podejście do zmian } \\
\text { i akceptacja } \\
\text { niepewności }\end{array}$ & $\begin{array}{l}\text { - Zorientowany } \\
\text { na kontynuację/exploiter } \\
\text { - Zorientowany na zmianę/ } \\
\text { explorer }\end{array}$ & $\begin{array}{l}\text { Hamel, Prahalad, 1993; } \\
\text { Liedtka, 1998; Johnson, 2007; } \\
\text { Godet, 2010; Sushil, 2012; } \\
\text { Olson, Simmerson, 2015 } \\
\end{array}$ \\
\hline $\begin{array}{l}\text { Postrzeganie otoczenia } \\
\text { konkurencyjnego } \\
\text { i podejście do innych } \\
\text { uczestników rynku }\end{array}$ & $\begin{array}{l}\text { - Otoczenie wrogie/ } \\
\text { zorientowany na walkę } \\
\text { - Otoczenie przyjazne/ } \\
\text { zorientowany na grę rynkową }\end{array}$ & $\begin{array}{l}\text { Crouch, 1998; Horowitz, } \\
\text { Kenerly, } 2014\end{array}$ \\
\hline $\begin{array}{l}\text { Przetwarzanie } \\
\text { informacji } \\
\text { i podejmowanie decyzji }\end{array}$ & $\begin{array}{l}\text { - Całościowa analiza/szybkie } \\
\text { decyzje } \\
\text { - Szczegółowa analiza/ } \\
\text { powolne decyzje }\end{array}$ & $\begin{array}{l}\text { - Eisenhardt, 1990; Heracleous, } \\
\text { 1998; Hodgkinson, Sparrow, } \\
\text { 2002; Steptoe-Warren, Howat, } \\
\text { Hume, 2011; Goldman, } \\
\text { Schlumpf, Scott, } 2017 \\
\end{array}$ \\
\hline $\begin{array}{l}\text { - Racjonalność } \\
\text { i kreatywność }\end{array}$ & $\begin{array}{l}\text { - Racjonalny/analityczny } \\
\text { - Twórczy/kreatywny }\end{array}$ & $\begin{array}{l}\text { - Mintzberg, 1994; Heracleous, } \\
\text { 1998; Jelenc, Swiercz, } 2011\end{array}$ \\
\hline \multicolumn{3}{|c|}{ Obszar metodyczny (proces) } \\
\hline Kryterium & Cecha & Referencje \\
\hline $\begin{array}{l}\text { - Zespołowość } \\
\text { w myśleniu } \\
\text { strategicznym }\end{array}$ & $\begin{array}{l}\text { - Myślenie indywidualne } \\
\text { - Myślenie grupowe }\end{array}$ & $\begin{array}{l}\text { Bonn, 2005; Johnson, 2007; } \\
\text { Goldman, Scott, Follman, } \\
\text { 2015; Olson, Simmerson, } 2015\end{array}$ \\
\hline $\begin{array}{l}\text { - Ciągłość/ } \\
\text { częstotliwość myślenia } \\
\text { strategicznego }\end{array}$ & $\begin{array}{l}\text { - Myślenie strategiczne } \\
\text { to ciągły proces } \\
\text { - Myślenie strategiczne } \\
\text { okazjonalne }\end{array}$ & - Johnson, 2007 \\
\hline $\begin{array}{l}\text { Celowość } \\
\text { i planowość myślenia } \\
\text { strategicznego }\end{array}$ & $\begin{array}{l}\text { - Myślenie strategiczne } \\
\text { to celowy, } \\
\text { zaplanowany proces } \\
\text { - Myślenie strategiczne } \\
\text { to wyłaniający się proces, } \\
\text { zmienny i nieplanowany }\end{array}$ & $\begin{array}{l}\text { - Mintzberg, 1994; Olson, } \\
\text { Simmerson, } 2015\end{array}$ \\
\hline
\end{tabular}

Źródto: opracowanie własne na podstawie przeglądu literatury. 


\section{W kierunku typologii - egzemplifikacja cech różnicujących strategów na podstawie studiów biograficznych}

Na podstawie wyprowadzonego z przeglądu literatury zestawienia cech różnicujących myślicieli strategicznych przeprowadzono badania biograficzne przedstawicieli świata biznesu. Ich podstawowe rezultaty opisano poniżej.

Strategiem zorientowanym na ciągłość i przejawiającym niską akceptację niepewności (exploiter) może być Andy Grove ${ }^{31}$. Podporządkowywał on strategię Intela prostym zasadom, jak na przykład prawu Moore’a (dotyczącemu podwajania mocy obliczeniowych co około 18-24 miesięcy) i ekonomii skali, koncentrował działalność firmy na wąskiej domenie działalności i ofercie produktowej oraz dążył do przywództwa kosztowego w sektorze ${ }^{32}$. Starał się zabezpieczyć przed radykalnymi zmianami technologicznymi na rynku, nie wchodził w obszary o wysokiej konkurencji (sprzęt komputerowy) i budował wysokie bariery wejścia (kapitałowe) na rynku mikroprocesorów, na którym Intel był liderem. Do ukazania jego działań i sposobu myślenia w jego opisach biograficznych często wykorzystywane są takie określenia jak: stopniowo, cyzelował, ograniczał, analizowat i doskonalit33.

Z kolei przykładem stratega zorientowanego na niepewność, zmianę i eksplorację jest Steve Jobs (Apple, Pixar, Next), który opracowywał produkty mające zmienić świat i styl życia ludzi. Innowacyjność i estetyka przeważały nad rentownością, jakość była ważniejsza niż ilość, inicjował wchodzenie w nowe technologie i obszary, w których nikt nie oferował wcześniej produktów (np. iTunes, animacja komputerowa w filmie). Ciągle wymyślał nowe produkty, eksperymentował i popełniał błędy (np. superkomputer Lisa, chmura Apple). Kierował się zasadą Henry'ego Forda, by nie pytać klientów o potrzeby, ale je wyprzedzać i kształtować. Otwarcie mówił też, że nie wierzy w opinie klientów i badania rynkowe ${ }^{34}$. W jego biografiach przeważają takie określenia jak rewolucyjny, zaskoczył, przełomowy, innowacyjny, chaotyczny, wizjonerski itp. ${ }^{35}$

31 Por. W.D. Miller, Value maps: valuation tools that unlock business wealth, John Wiley \& Sons, Hoboken 2010.

32 A.S. Grove, High output management, Vintage, New York 2015.

33 R. Heller, Andrew Grove, Dorling Kindersley, New York 2001; D.B. Yoffie, M.A. Cusumano, Strategy Rules...

34 D.B. Yoffie, M.A. Cusumano, Strategy Rules...

35 S. Gillam, Steve Jobs: Apple iCon, Apple iCon, ABDO, Minneapolis 2008; W. Isaacson, Steve Jobs, Simon \& Schuster, New York - Toronto 2011. 
Przykładem stratega zorientowanego na walkę jest Travis Kalanick, założyciel firmy Uber - aplikacji pozwalającej na zamawianie krótkich przejazdów u osób prywatnych. Kalanick, tworząc Ubera, założył, iż dążenie do zwycięstwa za wszelką cenę jest jedną z podstawowych wartości firmy, niezbędną do osiągnięcia przez nią sukcesu. W przedstawionym w 2009 roku kodeksie kulturowym firmy znajdują się takie punkty jak: „Zwycięstwo: umysł czempiona”, „Konfrontacja”, „Merytokracja i deptanie innym po nogach”. Co więcej, Kalanick uznał „zajadłość” za jedną z sześciu podstawowych wartości firmy. W przypadku niektórych praktyk Ubera wspomina się o działaniach na granicy etyki, a nawet prawa (np. odwrócona inżynieria aplikacji konkurencji, zamawianie fałszywych kursów w aplikacji konkurencji). W literaturze opisującej działania Ubera oraz Travisa Kalanicka dominują takie określenia jak: niebezpieczny, wojenny, jedna z bardziej rywalizujacych osób na świecie, hiperkonkurencyjny, agresywny, cały czas na wojnie ${ }^{36}$.

Przykładem stratega postrzegającego rynek jako grę z ustalonymi zasadami, zorientowanego na współpracę i grę jest Dirk Rossmann (drogerie Rossmann). W jego percepcji otoczenia, również konkurencyjnego, widoczny jest duży poziom zaufania do partnerów biznesowych i konkurentów. Jak sam zaznacza: „mimo konkurencji trzeba jednak działać fair. Moja zasada brzmi: nie być bezwzględnym, zwracać uwagę na innych ludzi"37. Efektem takiego postrzegania otoczenia były między innymi: wspólna organizacja zakupów z głównym konkurentem (DM) i dzielenie z nim rynku, a także organizowanie akcji charytatywnych wspólnie z największymi konkurentami i dostawcami. Przykładowo: w 1991 roku Dirk Rossmann zainicjował i zorganizował pomoc dla mieszkańców Moskwy, podkreślając, że akcja ta „świadczy o tym, że konkurenci potrafią ze sobą współdziałać, gdy przychodzi co do czego"38. Jak podkreśla, chętnie budował i utrzymywał relacje prywatne i przyjacielskie z właścicielami firm konkurencyjnych i działających w tym samym otoczeniu. W opisie jego działań często wykorzystywane są określenia: zasady, gra, relacje, przyjaźń, zaufanie, fair.

Przykładem osoby dokonującej szczegółowych analiz strategicznych jest Bill Gates - założyciel Microsoftu oraz fundacji Melindy i Billa Gatesów. Miliarder słynie ze szczegółowego analizowania wszystkich zmiennych przed podjęciem decyzji. Kieruje się logicznym rygorem oraz precyzją w myśleniu i komunikacji ${ }^{39}$.

36 B. Horowitz, What You Do Is Who You Are How to Create Your Business Culture, Harper Busines, New York 2019.

37 Rossmann D., Käfferlein P., Köhne O., „... i wtedy wspiq̨łem się na drzewo”, Wydawnictwo Znak, Kraków 2019, s. 207

38 Tamże, s. 205.

39 W. Isaacson, The Innovators: How a Group of Hackers, Geniuses, and Geeks Created the Digital Revolution, Simon \& Schuster, New York 2014. 
Jednocześnie, gdy na przykład pracuje nad dotychczas nieznanym sobie tematem, stara się spotkać z ekspertami i przeczytać jak najwięcej pozycji na dany temat. Słynie z tego, iż dwa razy do roku wyjeżdża na „tydzień myślenia”, by zwolnić, przemyśleć dotychczasowe kroki i strategię. Podczas wyjazdów czyta, wymyśla nowe koncepcje i notuje. Właśnie w trakcie takiego wyjazdy wymyślił przeglądarkę Internet Explorer i zbudował strategię Microsoftu dotyczącą przyszłości komunikacji ${ }^{40}$. W opisach o nim pojawiają się informacje, iż zawsze wie więcej o innych na dany temat, potrafi przeczytać 150 stron na godzinę i zapamiętać $90 \% \mathrm{z}$ tego, jego mózg to multiprocesor, w jego głowie cały czas coś się dzieje, cały czas coś analizuje, wszystko zapamiętuje ze szczegółami, studiuje wszystko bardzo dokładnie, robi notatki ${ }^{41}$.

Strategiem, który zbudował cały swój biznes na stosunkowo prostych, globalnych założeniach, jest Jeff Bezos, założyciel firmy Amazon, który słynie z szybkiego podejmowania decyzji. Amazon oparty jest na trzech filarach: najniższej cenie, najszybszej dostawie, największym wyborze produktów, które są stałe w długoterminowej strategii firmy ${ }^{42}$. Bezos dzieli przedsiębiorstwa na dwa rodzaje: firmy dnia pierwszego i dnia drugiego. Firmy dnia pierwszego to te, które ciągle i nieustannie się zmieniają, szybko podejmują decyzje, są innowacyjne i witalne. Firmy dnia drugiego to zastój i powolny upadek. Regularnie opisując swój model biznesowy, Bezos stwierdza, że prędkość jest wyjątkowo ważna w biznesie; podejmowanie szybkich decyzji, gdy posiada się jedynie szczątkowe informacje, jest kluczowe, by szybko rosnąć, a szczegółowe analizy sprawiają, iż firma staje się przedsiębiorstwem „dnia pierwszego”. Do każdego ze swoich listów do akcjonariuszy Bezos dołącza swój pierwszy dokument z 1997 roku i kończy pismo stwierdzeniem: „dla Amazonu zawsze jest dzień pierwszy"43.

Strategiem racjonalnym, analitycznym, metodycznym i wolnym od emocji jest Elon Musk, założyciel firm PayPal, Tesla, SpaceX i Hyperloop. Przedsiębiorca znany jest $\mathrm{z}$ tego, że w swoich strategiach i podejściu do biznesu kieruje się najnowocześniejszymi osiągnięciami nauki (np. energia słoneczna, autonomiczne samochody, tunele z hiperszybkimi pojazdami) oraz eksperymentami myślowymi (np. ile musi kosztować rakieta, by móc ją wysłać w kosmos). Według opisów „strategia

40 B. Gates, J. Ottavino, Road Ahead, High Bridge Company, UK 1995.

41 D. Guggenheim, Inside Bill's Brain: Decoding Bill Gates, 2019, https://www.netflix.com/title /80184771 (dostęp: 16.12.2019).

42 B. Stone, The Everything Store: Jeff Bezos and the Age of Amazon, Atlantic/Little, Brown, Boston 2013.

43 J.P. Bezos, Amazon 2016 Annual Report: Letter to shareholders, 2016, s. 2, http://www.an nualreports.com/HostedData/AnnualReportArchive/a/NASDAQ_AMZN_2016.pdf (dostęp: 2.02.2020). 
i intelekt pozwalają mu przejść przez świat”, co jest też istotne w sytuacjach kryzysowych, "gdy wszyscy stają w obliczu presji, zaczynają popełniać błędy; Elon staje się hiperracjonalny i skoncentrowany" 44 . Elon Musk słynie z technokratycznego podejścia do budowania biznesu, nierzadko „nieludzkiego” w stosunku do pracowników (np. nadgodziny, presja na wyniki, zmiany).

Przykładem osoby kierującej się w decyzjach strategicznych intuicją oraz emocjami, kreatywnością i doświadczeniami jest Howard Schultz - założyciel i pierwszy dyrektor generalny firmy Starbucks. Sam uznaje, że w biznesie należy kierować się sercem, nastawiając się na emocje, doświadczenie klienta i jego obsługę. Zastanawiając się nad sukcesem Strabucksa, uznaje, że właśnie dzięki temu mała kawiarnia stała się globalnym graczem na rynku. Często kierował się intuicją, testami oraz wyczuciem rynku, między innymi wprowadzając produkt frappuccino, czyli produkt roku 1996 w Stanach Zjednoczonych. Według Schultza: „nie kierowaliśmy się żadną wielką analizą finansową, nie zatrudniliśmy konsultantów, którzy dostarczyliby 10000 stron slajdów. Nie było żadnej biurokracji"45.

Przykładem osoby starającej się kreować strategię w sposób kolektywny, demokratyczny, oparty na opiniach ludzi z różnych szczebli jest Phil Knight - założyciel i pierwszy prezes firmy Nike. Słynął on z dawania dużej swobody swoim pracownikom i menedżerom. Komunikacja dwustronna była kluczowa w procesie decyzyjnym, dzięki czemu każdy głos był uwzględniany. Główny zespół liderów w Nike był: „spójny pod względem celów i wysiłków [...] byliśmy wobec siebie bezlitośni, szczerzy i nienawistni w dyskusji, co pozwalało na trzymanie naszego ego w spokoju, nigdy nie było najmądrzejszego człowieka w pomieszczeniu, bo każdy był równie mądry"46. Jednocześnie regularnie pytano pracowników o opinie, na przykład w kontekście utworzenia nazwy „Nike” przeprowadzono ankietę oraz kilkakrotnie burze mózgów. Co więcej, firma zatrudniała zewnętrznych konsultantów, którzy pomagali w strategicznych decyzjach, na przykład dotyczących lokacji fabryk w Azji lub w przypadku pierwszych kontraktów reklamowych ${ }^{47}$.

Osobą, która charakteryzuje się indywidualnym i jednostkowym podejściem do strategii, kierunkowaniem jej od osoby „guru”, jest Mark Zuckerberg - założyciel Facebooka. Słynie on z charyzmatycznego i wizjonerskiego podejścia do rozwijania firmy. Otacza się wąskim sztabem zaufanych ludzi, nazywanych przez pracowników „porucznikami” - im ktoś siedzi bliżej biura prezesa, tym jest

44 A. Vance, Elon Musk: Tesla, SpaceX, and the Quest for a Fantastic Future, Ecco, New York 2015, s. 408.

45 H. Schultz, Pour Your Heart Into It: How Starbucks Built a Company One Cup at a Time, Hyperion, New York 1997, s. 350.

46 P. Knight, Shoe Dog, Scribner Book Company, New York 2016, s. 541.

47 Tamże. 
ważniejszą osobą w firmie. W przypadku kierunków strategicznych, na przykład dotyczących reklam na platformie, Zuckerberg jest wysoce precyzyjny, każda ważna decyzja przechodzi przez niego ${ }^{48}$. Założyciel Facebooka jest również "guru” firmy. Powszechnie znane są jego hasła i slogany: „poruszaj się szybko i psuj rzeczy”, „poruszaj się szybko, ze stabilną infrastrukturą", „zrobione jest lepsze niż perfekcyjne” lub „ta podróż jest ukończona tylko w 1\%”, które definiują styl pracy w firmie i nadają ton kulturowy całej organizacji. W przypadku Zuckerberga częste są określenia takie jak: otacza się pięcioma kluczowymi ludźmi, jest przekonany, dominować, fundamentalnie pewny ${ }^{49}$.

Biorąc pod uwagę kryterium częstotliwości i intensywność myślenia strategicznego, przykładem stratega okazjonalnego jest Warren Buffet - inwestor, filantrop i założyciel funduszu Berkshire Hathaway. Mimo iż dostosował swoją codzienną rutynę do sprawdzania wyników finansowych, koszt śniadań uzależnił od tego, czy giełda otworzyła się z zyskiem lub stratą, codziennie czyta 500 stron raportów, gazet i książek, jego proces decyzyjny jest systematyczny, ale okazjonalny i wybiór$\mathrm{czy}^{50}$. Inwestor znany jest $\mathrm{z}$ tego, że podejmuje trzy strategiczne decyzje $\mathrm{w}$ ciągu roku ${ }^{51}$. Decyzje inwestycyjne Buffetta nie są oparte na „ostatnich, gorących trendach rynkowych, ale na określonych i z góry ustalonych szansach, w które wierzy, że są niedowartościowane"52. Warren Buffett regularnie publikuje też listy do akcjonariuszy, które pokazują jego podejście do inwestowania, między innymi stosunkowo rzadkie zmiany w portfolio firmy, decyzje ad hoc oparte na szansach, realizację inwestycji od czasu do czasu, by maksymalnie zabezpieczyć interesy akcjonariuszy ${ }^{53}$.

Przykładem osoby, dla której myślenie strategiczne ma charakter ciągły, jest częścią codziennej pracy, rytuałów, jest Jack Welch - były dyrektor generalny General Electric. Jak sam określił: „strategia jest dla mnie żyjącą, oddychającą, totalnie dynamiczną grą. Jest zabawna, szybka i jest żywa [...] to ciągły, przybliżony

48 Martinez G.A., Chaos Monkeys, Harper Business, New York 2016.

49 E. Walter, Think Like Zuck: The Five Business Secrets of Facebook's Improbably Brilliant CEO Mark Zuckerberg, 2013, http://www.amazon.com/Think-Like-Zuck-Improbably-Zuckerberg /dp/007180949X (dostęp: 2.01.2020).

50 K. Peter, B. Oakes, Becoming Warren Buffett, 2017, http://www.hbo.pl/movie/byc-jak-war ren-buffett_-86385 (dostęp: 16.12.2019).

51 T. Huddleston Jr., Jeff Bezos, Warren Buffett and Barack Obama all use this decision-making strategy, CNBC, 2018, https://www.cnbc.com/2019/02/26/bezos-buffett-obama-zuckerbe rg-use-this-decision-making-strategy.html (dostęp: 16.12.2019).

52 R. Hagstrom, The Warren Buffett Way, 2005, https://doi.org/10.1016/j.patrec.2005.01.006

53 D. Pecaut, C. Wrenn, University of Berkshire Hathaway: 30 Years of Lessons Learned from Warren Buffett \& Charlie Munger at the Annual Shareholders Meeting, Pecaut and Company, La Vergne 2017. 
kurs, który często definiujesz, zmieniasz i dostosowujesz do zmieniających się warunków rynkowych. To proces iteratywny" 54 . W przypadku Welcha można mówić o nieustannym myśleniu strategicznym, powiązanym z inicjatywami, na przykład wprowadzeniem six sigma, strategii nr 1 lub nr 2 na rynku czy handlu internetowego $^{55}$. Skupiając się na ludziach, Welch regularnie dyskutował na temat strategicznych aspektów organizacji: misji, wizji, kluczowych celów, w charakterystyczny, rytualny wręcz sposób, na przykład pokazując trzy kręgi, na których należy się skupić w kontekście linii biznesowych. Aspekty strategiczne były częścią nieustannej pracy Welcha, o czym regularnie wspomina również w swoich książkach, biografii oraz wywiadach ${ }^{56}$.

Strategiem zorientowanym na myślenie zaplanowane, ułożone, poprzedzające planowanie strategiczne, oparte na głównym scenariuszu, jest Tim Cook - nowy dyrektor generalny Apple. Cook przejął firmę po śmierci Steve’a Jobsa, który wyznaczył ogólną wizję rozwoju przedsiębiorstwa po jego odejściu. Pomimo tego Cook opracował nową misję i wizję rozwoju Apple, przyjął określony scenariusz rozwoju produktów i konsekwentnie go rozwija. Cook uznał, że: „nie zamierza niszczyć i zmieniać tego, co już dobrze działa i odbudowywać tego, jest stałym kapitanem i zamierza utrzymać statek na stabilnym kursie" 57. By utrzymać rosnącą wartość firmy, Cook wymyślił i zaplanował nowe wartości firmy, które nie zostały oficjalnie uznane, ale oddają jego styl przywództwa - żadne odstępstwo od nich nie jest tolerowane i jako dyrektor generalny przykłada do tego dużą wagę. Przewijające się określenia na jego temat to: stały, stabilny, harmonijny, pracuje zgodnie z ustalonym wcześniej systemem, niezmienny ${ }^{58}$.

Przykładem stratega korzystającego z wyłaniających się okazji i preferującego zmienne i nieplanowane procesy, może być Samuel Walton w pierwszych latach istnienia Wal-Martu, największej na świecie sieci sklepów detalicznych. Regularnie wspominał, że: „zmienne kursy akcji i presja zmuszały nas do zmiany stylu zarządzania. Czasem myśleliśmy krótko, czasem długoterminowo. Gdy otwierasz 150 sklepów rocznie, dużo twojego planowania jest krótkoterminowego"59. Stwierdził on, że strategia wzrostu Wal-Martu oparta była na konieczności i wykorzystaniu

54 J. Welch, S. Welch, Winning, Harper Business, New York 2005, s. 80.

55 K. Jensen, The Jack Welch Lexicon of Leadership: Over 250 Terms, Concepts, Strategies \& Initiatives of the Legendary Leader, "Quality Management Journal” 2002, vol. 9, no. 3, s. 68-69.

56 J. Welch, J.A. Byrne, M. Barnicle, Jack: Straight from the Gut, 2005, http://www.straightfro mthegut.com (dostęp: 16.12.2019).

57 L. Kahney, Tim Cook: The Genius Who Took Apple to the Next Level, Penguin Publishing Group, New York 2019, s. 27.

58 Tamże.

59 S. Walton, Made in America. My Story, Bantam Books, New York 1993, s. 228. 
szans rynkowych, nie planowano wejścia do danego miasta, tylko rozszerzano działalność w zależności od okazji. Co więcej, podejście Waltona do strategii było nierzadko oportunistyczne: „lubiłem zmienić kurs mojego samolotu, wylądować w danej miejscowości, znaleźć kawałek ziemi i zacząć od razu negocjacje z właścicielem, gdy widziałem okazje"60.

Zaprezentowane powyżej przykłady znanych strategów pokazują przekrojowo sposoby myślenia liderów i naturalnie nie wyczerpują podjętego tematu.

\section{Podsumowanie}

W rozdziale syntetycznie zaprezentowano podstawowe rezultaty dwóch pierwszych etapów prowadzonego postępowania badawczego w zakresie identyfikacji typów strategów i sposobów myślenia strategicznego. Przedstawiono wyniki przeglądu i analizy literatury oraz badań biograficznych. Ze względu na fakt, iż prowadzone przez autorów badania nad cechami różnicującymi myślicieli strategicznych i ich egzemplifikacjami są obecnie w toku, przedstawione zestawienie cech różnicujących oraz sposób ich podziału i uporządkowania traktować należy jako pewną propozycję, która może ulec modyfikacji i rozszerzeniu w wyniku kontynuacji i pogłębiania zarówno badań literaturowych, jak i empirycznych (kolejne etapy postępowania badawczego).

W przypadku metody biograficznej należy wziąć pod uwagę dostępność pozycji, które zazwyczaj opisują historie i sposoby myślenia osób wyrazistych, nierzadko kontrowersyjnych. Ze względu na popularność tego typu publikacji obserwuje się głównie liderów z europejsko-amerykańskiego kręgu kulturowego, w większości mężczyzn, którzy osiągnęli sukces. Wymienieni przez autorów stratedzy również należą do tej grupy, ich przykłady należy zatem analizować jako wstępne i nierzadko skrajne ilustracje badanego zjawiska. W przypadku dalszych badań niezbędne jest poszerzenie dotychczasowej grupy o osoby spoza zbioru, jak również dotarcie poprzez badania jakościowe (obecnie w toku) do menedżerów mniej znanych, którzy także podejmują decyzje strategiczne.

Jak wstępnie zasygnalizowano, kolejnym krokiem w postępowaniu badawczym będzie operacjonalizacja zidentyfikowanych cech i propozycja sposobu ich pomiaru. Niewątpliwie stanowi to duże wyzwanie metodyczne, ponieważ poszczególne cechy różnicujące strategów identyfikowane były przez autorów przeanalizowanych publikacji w bardzo różnych badaniach (inne podejścia badawcze, różne sposoby doboru próby, odmienne techniki gromadzenia i analizy danych itd.), trudnych do porównań. Niektórzy autorzy traktują bowiem poszczególne wartości cech

60 Tamże, s. 229. 
jako dychotomiczne ${ }^{61}$, inni ujmują je w kategoriach przeciwnych krańców kontinuum, z możliwością osiągania niezliczonych stanów pośrednich ${ }^{62}$, podczas gdy jeszcze inni proponują łączenie tych przeciwieństw, pozostając w nurcie autorów podkreślających konieczność uwzględniania dialektyki, łączenia paradoksów czy oburęczności (ambidexterity) ${ }^{63}$.

Bibliografia

Amitabh M., Sahay A., Strategic Thinking: Is Leadership the Missing Link, 2007, http://www.iitk .ac.in/infocell/announce/convention/papers/Strategy-01-ManuAmitabhfinal.pdf (dostęp: 2.02.2020).

Bezos J.P., Amazon 2016 Annual Report: Letter to shareholders, 2016, http://www.annualreports .com/HostedData/AnnualReportArchive/a/NASDAQ_AMZN_2016.pdf (dostęp: 2.02.2020).

Bonn I., Improving strategic thinking: a multilevel approach, „Leadership \& Organization Development Journal" 2005, vol. 26, no. 5, s. 336-354.

Booth A., Sutton A., Papaioannou D., Systematic approaches to a successful literature review, Sage, London 2016.

Bornat J., Biographical methods. The Sage Handbook of Social Research Methods, Sage, London 2008.

Bowman E.H., Helfat C.E., Does corporate strategy matter?, „Strategic Management Journal” 2001, vol. 22, no. 1, s. 1-23.

Brandon J., Toward a reconsideration of biography as an instrument for studying leadership in educational administration, „Canadian Journal of Educational Administration and Policy" 2002, vol. 21, http://www.umanitoba.ca/publications/cjeap/articles/brandon.html (dostęp: 2.02.2020).

Crouch A., Reframing the strategic problem: An accommodation of harmony and belligerence in strategic management, „Journal of Business Research” 1998, vol. 41, no. 1, s. 3-13.

Czakon W., Metodyka systematycznego przeglądu literatury, „Przegląd Organizacji” 2011, nr 3, s. 57-61.

Danzig A.B., Leadership stories: What novices learn by crafting the stories of experienced school administrators, „Journal of Educational Administration” 1997, vol. 35, no. 2, s. 122-137.

Dhir S., Dhir S., Samanta P., Defining and developing a scale to measure strategic thinking, „Foresight" 2018, vol. 20, no. 3, s. 271-288.

Dutta K., Strategic Thinking as a Differentiator in Entrepreneurial Cognition, „The IUP Journal of Entrepreneurship Development" 2015, vol. 12, no. 2, s. 7-23.

Eisenhardt K.M., Speed and Strategic Choice: How Managers Accelerate Decision Making, „California Management Review" 1990, vol. 32, no. 3, s. 39-54.

Gates B., Ottavino J., Road Ahead, High Bridge Company, UK 1995.

Gillam S., Steve Jobs: Apple iCon, Apple iCon, ABDO, Minneapolis 2008.

61 Na przykład J.M. Liedtka, Strategic thinking...

62 A.K. Olson, B.K. Simerson, Leading with strategic thinking...

63 D. Sage, A. Dainty, N. Brookes, A consideration of reflexive practice within the critical projects movement, „International Journal of Project Management” 2010, vol. 28, no. 6, s. 539-546; Sushil, Flowing stream strategy: Managing confluence of continuity and change, „Journal of Enterprise Transformation" 2012, vol. 2, no. 1, s. 26-49. 
Godet M., Future memories, „Technological Forecasting and Social Change” 2010, vol. 77, no. 9, s. $1457-1463$.

Goldman E.F., Schlumpf K.S., Scott A.R., Combining practice and theory to assess strategic thinking, „Journal of Strategy and Management” 2017, vol. 10, no. 4, s. 488-504.

Goldman E.F., Scott A.R., Follman J.M., Organizational practices to develop strategic thinking, „Journal of Strategy and Management” 2015, vol. 8, no. 2, s. 155-175.

Grove A.S., High output management, Vintage, New York 2015.

Guggenheim D., Inside Bill's Brain: Decoding Bill Gates, 2019, https://www.netflix.com/title/801 84771 (dostęp: 16.12.2019).

Gunter H., Leaders and leadership in education, Sage, London 2001.

Hagstrom R., The Warren Buffett Way, 2005, https://doi.org/10.1016/j.patrec.2005.01.006

Hamel G., Prahalad C.K., Strategy as stretch and leverage, „Harvard Business Review” 1993, vol. 71, no. 2, s. 75-84.

Hanford P., Developing Director and Executive Competencies in Strategic Thinking, [w:] B. Garratt (red.), Developing Strategic Thought: Reinventing the Art of Direction-Giving, McGraw-Hill, London 1995, s. 188-222.

Haycock K., Cheadle A., Bluestone K.S., Strategic Thinking Lessons for Leadership from the Literature, „Library Leadership and Management” 2012, vol. 26, no. 3/4, s. 1-23.

Heller R., Andrew Grove, Dorling Kindersley, New York 2001.

Heracleous L., Strategic thinking or strategic planning?, „Long Range Planning” 1998, vol. 31, no. 3, s. 481-487.

Hodgkinson G.P., Sparrow P.R., The Competent Organization: A Psychological Analysis of the Strategic Management Process, Open University Press, Buckingham 2002.

Horowitz B., What You Do Is Who You Are How to Create Your Business Culture, Harper Busines, New York 2019.

Horowitz B., Kenerly K., The hard thing about hard things: building a business when there are no easy answers, Harper Business, New York 2014.

Huddleston Jr. T., Jeff Bezos, Warren Buffett and Barack Obama all use this decision-making strategy, CNBC, 2018, https://www.cnbc.com/2019/02/26/bezos-buffett-obama-zuckerberg -use-this-decision-making-strategy.html (dostęp: 16.12.2019).

Isaacson W., Steve Jobs, Simon \& Schuster, New York - Toronto 2011.

Isaacson W., The Innovators: How a Group of Hackers, Geniuses, and Geeks Created the Digital Revolution, Simon \& Schuster, New York 2014.

Jelenc L., Swiercz P.M., Strategic thinking capability: Conceptualization and measurement, 56th Annual ICSB World Conference, Stockholm, 15-18 June 2011, http://www.icsb2011.org/do wnload/18.62efe22412f41132d41800012398/310.pdf (dostęp: 2.01.2020).

Jensen K., The Jack Welch Lexicon of Leadership: Over 250 Terms, Concepts, Strategies \& Initiatives of the Legendary Leader, "Quality Management Journal” 2002, vol. 9, no. 3, s. 68-69.

Johnson G., Ritualizing strategic thinking: the effectiveness of the strategic away day, „Strategic Direction" 2007, vol. 24, no. 1, s. 3-5.

Kahney L., Tim Cook: The Genius Who Took Apple to the Next Level, Penguin Publishing Group, New York 2019.

Knight P., Shoe Dog, Scribner Book Company, New York 2016.

Liedtka J.M., Strategic thinking: can it be taught?, „Long Range Planning” 1998, vol. 31, no. 1, s. $120-129$.

Martinez G.A., Chaos Monkeys, Harper Business, New York 2016.

Miller W.D., Value maps: valuation tools that unlock business wealth, John Wiley \& Sons, Hoboken 2010. 
Mintzberg H., The Rise and Fall of Strategic Planning, Hertfordshire Free Press and Prentice Hall International, London 1994.

Nuntamanop P., Kauranen I., Igel B., A new model of strategic thinking competency, „Journal of Strategy and Management" 2013, vol. 6, no. 3, s. 242-264.

Olson A.K., Simerson B.K., Leading with strategic thinking: Four ways effective leaders gain insight, drive change, and get results, John Wiley \& Sons, Hoboken 2015.

Palaima T., Skaržauskienè A., Systems thinking as a platform for leadership performance in a complex world, „Baltic Journal of Management” 2010, vol. 5, no. 3, s. 330-355.

Pecaut D., Wrenn C., University of Berkshire Hathaway: 30 Years of Lessons Learned from Warren Buffett \& Charlie Munger at the Annual Shareholders Meeting, Pecaut and Company, La Vergne 2017.

Peter K., Oakes B., Becoming Warren Buffett, 2017, http://www.hbo.pl/movie/byc-jak-warren-buf fett_-86385 (dostęp: 16.12.2019).

Petticrew M., Roberts H., Systematic Reviews in the Social Sciences: A Practical Guide, Blackwell, Oxford 2006.

Pisapia J., The Strategic Leader: New Tactics for a Globalizing, Information Age Publishing, USA 2009.

Porter M.E., On competition, Harvard Business Press, Boston 2008.

Ribeiro C.R., „Thought of the outside”, knowledge and thought in education: conversations with Michel Foucault, „Educação e Pesquisa” 2011, vol. 37, no. 3, s. 613-628.

Rossmann D., Käfferlein P., Köhne O., „... i wtedy wspiątem się na drzewo”, Wydawnictwo Znak, Kraków 2019.

Rouse W., Technology for Strategic Thinking, „Strategy \& Leadership” 1997, vol. 25, no. 1, s. 40-41.

Sage D., Dainty A., Brookes N., A consideration of reflexive practice within the critical projects movement, „International Journal of Project Management” 2010, vol. 28, no. 6, s. 539-546.

Schachter D.L., Gilbert D.T., Wegner D.M., Nock M.K., Introducing psychology, Worth, New York 2015.

Schultz H., Pour Your Heart Into It: How Starbucks Built a Company One Cup at a Time, Hyperion, New York 1997.

Steptoe-Warren G., Howat D., Hume I., Strategic thinking and decision making: literature review, „Journal of Strategy and Management” 2011, vol. 4, no. 3, s. 238-250.

Stone B., The Everything Store: Jeff Bezos and the Age of Amazon, Atlantic/Little, Brown, Boston 2013.

Sushil, Flowing stream strategy: Managing confluence of continuity and change, „Journal of Enterprise Transformation" 2012, vol. 2, no. 1, s. 26-49.

Tavakoli I., Lawton J., Strategic thinking and knowledge management, „Handbook of Business Strategy" 2005, vol. 6, no. 1, s. 155-160.

Vance A., Elon Musk: Tesla, SpaceX, and the Quest for a Fantastic Future, Ecco, New York 2015.

Walter E., Think Like Zuck: The Five Business Secrets of Facebook's Improbably Brilliant CEO Mark Zuckerberg, 2013, http://www.amazon.com/Think-Like-Zuck-Improbably-Zuckerberg/dp /007180949X (dostęp: 2.01.2020).

Welch J., Welch S., Winning, Harper Business, New York 2005.

Welch J., Byrne J.A., Barnicle M., Jack: Straight from the Gut, 2005, http://www.straightfromthe gut.com (dostęp: 16.12.2019).

Yoffie D.B., Cusumano M.A., Strategy Rules: Five Timeless Lessons from Bill Gates, Andy Grove, and Steve Jobs, Harper Business, New York 2015. 


\section{Streszczenie}

Celem podjętych badań było przedstawienie podstaw teoretycznych koncepcji myślenia strategicznego i myślicieli strategicznych, a także cech różnicujących strategów. Pogłębiona analiza literatury pozwoliła ustalić, jak najczęściej rozumiane jest myślenie strategiczne i co stanowi jego istotę, a także kim jest myśliciel strategiczny, za co w organizacji odpowiada i jakie cechy wyróżniają go wśród innych liderów. W rozdziale wskazano także na różnice występujące pomiędzy myślicielami strategicznymi, identyfikując tym samym lukę badawczą dotyczącą typologii strategów (strategic thinkers). Dzięki przeprowadzonym studiom biograficznym poszczególne typy myślicieli strategicznych zostały zilustrowane przykładami znanych postaci ze świata biznesu.

Słowa kluczowe: myślenie strategiczne, stratedzy, myśliciele strategiczni, cechy różnicujące, badania biograficzne

\section{Strategic thinkers: a literature review and biographical studies}

\section{Abstract}

The main goal of the research was to present fundamental conceptualisations of strategic thinking and strategic thinkers. A thorough literature review led to conceptual conclusions with regards to the understanding of strategic thinking definitions and strategic thinkers' place in the organisation, as well as characteristics differentiating them from other types of leaders. In the manuscript we also present how strategists vary, forming specific types of strategic thinkers. This led to the identification of a research gap and a goal of strategic thinkers' typology development. Thanks to biographic studies all strategic thinker types have been illustrated with examples of well-known business leaders.

Keywords: strategic thinking, strategic thinkers, differentiating features, biographical studies 